\title{
Jurisdiction over Interstate Felony Murder
}

Suppose a felony committed in one state results in a death in another state and the alleged perpetrator is prosecuted for homicide under the felony-murder rule. The law is not settled as to which state or states may exercise jurisdiction over the crime. Only three states ${ }^{1}$ have confronted this issue, and the courts involved relied on differing rationales to reach disparate conclusions. ${ }^{2} \mathrm{De}$ spite the narrowness of the problem posed, its resolution raises larger questions as to the analysis appropriate for deciding questions of jurisdiction over interstate crime generally.

This comment examines current approaches to jurisdiction over interstate crime and demonstrates that their failure to provide satisfactory solutions for interstate felony murders is the result of their inadequate analyses of the state interests served by an assertion of jurisdiction. The comment will analyze those interests and consider the extent to which various rationales for felony murder implicate them. Finally, the comment will propose that only the felony state's interests are sufficient to justify the assertion of jurisdiction over interstate felony murder.

\section{INTRODUCTION}

The law of jurisdiction over interstate felony murder is remarkable mostly for its lack of clarity. Recent decisions reveal no overriding principles, but rather reflect a variety of distinct ideas. Scrutiny of the decisions, however, permits identification of three possible approaches to the problem of jurisdiction over interstate felony murders.

In People v. Holt, ${ }^{3}$ the evidence showed that Holt kidnapped the victim in Illinois and took her to Wisconsin where he raped and strangled her. The Illinois Supreme Court reversed the felonymurder conviction on jurisdictional grounds. Interpreting the Illinois statute governing criminal jurisdiction, ${ }^{4}$ the court essentially

\footnotetext{
1 Florida, Mlinois, and New Jersey. See infra notes 3-14 and accompanying text.

2 See infra notes 3-14 and accompanying text.

- 91 III. 2d 480, 482-83, 440 N.E.2d 102, 103 (1982).

- Criminal Code of 1961 \& 1-5, Ill. Rev. Stat. ch. 38, § 1-5 (1981).
} 
adopted the common law analysis..$^{5}$ Not every element of a crime, the court concluded, is sufficient to confer jurisdiction; only certain essential elements constituting the "gist" or "gravamen" of the offense will suffice. ${ }^{B}$ The underlying felony, the court went on to hold, is not such an element of felony murder. ${ }^{7}$

In State v. Reldan, ${ }^{8}$ the court focused on the offense-related activity of the defendant within the state and whether the totality of that activity was sufficient to form a basis for jurisdiction. The court held that in-state commission of a felony suffices to establish jurisdiction over a felony murder even when the death occurs in another state. ${ }^{\circ}$ Unfortunately, the court's opinion neither explains

- See infra notes 15-22 and accompanying text.

- 91 IIl. $2 \mathrm{~d}$ at 487,440 N.E.2d at 105.

T Id. at 484, 487-88, 440 N.E.2d at 104, 105-06. The court indicated that "[a] felony might support jurisdiction if there were some intrinsic relation between it and the death." Id. at 486,440 N.E.2d at 104 .

${ }^{8} 166$ N.J. Super. 562, 400 A.2d 138 (Law Div. 1979). In Reldan, the defendant was charged with both felony murder and premeditated murder for the kidnappings and subsequent deaths of two women. The defendant challenged the New Jersey court's jurisdiction, arguing that since the bodies were found in New York, the killings must be presumed to have occurred there. The court bypassed this argument, finding that the commission of an underlying kidnapping in New Jersey was sufficient to confer jurisdiction over a felonymurder offense on New Jersey courts regardless of where the killing occurred. Id. at 567, 400 A.2d at 141. The court based its holding on "the well-established principle that a sovereign has jurisdiction to try an offense where only part of that offense has been committed within its boundaries." Id. The court failed to analyze this principle, which, while it may be wellestablished, is statutory in origin and unknown at common law. See Berge, Criminal Jurisdiction and the Territorial Principle, 30 Mrch. L. REv. 238, 239-40 (1931); Levitt, Jurisdiction Over Crimes, 16 J. Crim. L. \& Criminology 316, 324-25, 331-33 (1925); Perkins, The Territorial Principle in Criminal Law, 22 Hastings L.J. 1155, 1157-62 (1971). New Jersey has no statute dealing with criminal jurisdiction, but relies instead on common law.

- See 166 N.J. Super. at 567, 400 A.2d at 141; see also Lane v. State, 388 So. 2d 1022, 1027-28 (Fla. 1980) (per curiam) (Florida has jurisdiction over an alleged premeditated murder where "essential elements of the offense may be . . . established beyond a reasonable doubt in Florida even though the fatal blow and the victim's death" occur elsewhere.). Although the charge in Lane was premeditated murder, the court's analysis is applicable to felony murder. In Lane, the defendant rendered the victim unconscious during an attempted robbery in Florida, then drove with the victim to Alabama where the killing took place. Id. at 1023. Applying a statute providing that the state has jurisdiction when "either the conduct that is an element of the offense or the result that is an element occurs within the state," Fla. STAT. ANN. \$ 910.005(2) (West 1973), the court held that "[o]ne of the essential elements of this offense is the premeditated design of the appellant to effect the death of the victim or, in the alternative, the perpetration of or an attempt to perpetrate a robbery upon the victim," 388 So. $2 \mathrm{~d}$ at 1028 . This analysis, as applied to premeditated murder, is open to question since the statute speaks of conduct, not merely intent, as required to establish jurisdiction and since the alternative element, attempted robbery, is not an element of premeditated murder. Nevertheless, it seems clear that, had the homicide in Lane been prosecuted under felony-murder principles, the court would have held the commission of attempted robbery in Florida sufficient to establish jurisdiction over the killing. Accord, People v. Holt, 91 III. 2d 480, 500, 440 N.E.2d 102, 111 (1982) (Moran, J., dissent- 
the grounds for reaching this conclusion nor defines a definite jurisdictional threshold. However, the court in Holt, which used this approach as well as the common law "gist of the offense" test in its decision,,$^{10}$ noted that acts which constitute an attempt are sufficient to meet the jurisdictional threshold. ${ }^{11}$ While conceding that a threshold lower than attempt might be proper, the Holt court held that in-state commission of the bare felony is insufficient to confer jurisdiction over felony murder. ${ }^{12}$

A third approach, not yet applied to felony-murder cases but worthy of discussion, is the "integral relation" approach used by the courts of Indiana. ${ }^{13}$ Under this approach, the felony state would be able to exercise jurisdiction over felony murder when there is substantial evidence of an integral relation between the felony and the resultant death, even if the death occurred outside the state. ${ }^{14}$

The next section presents these three approaches-common law, "sufficiency of activity," and "integral relation"-as possible solutions to the problem of jurisdiction over interstate felony murder.

\section{Current Approaches to Criminal Jurisdiction}

\section{A. The Common Law Approach}

Criminal jurisdiction at common law is based almost exclusively on principles of territoriality: ${ }^{15}$ a sovereign has absolute and exclusive sovereignty over crimes committed in its territory. ${ }^{18}$ Consequently, an offender may be prosecuted only in the place where the offense is committed. ${ }^{17}$ This requirement is both reasonable

ing) (interpreting Lane in this manner).

10 See supra notes 3-7 and accompanying text.

11 Holt, 91 Ill. $2 d$ at 489 , 440 N.E.2d at 106.

12 Id. at $480,485-86,488-89,440$ N.E.2d at 102, 104, 105-06.

13 See Pollard v. State, 270 Ind. 599, 602-03, 388 N.E.2d 496, 501 (1979); Conrad v. State, 262 Ind. 446, 450-51, 317 N.E.2d 789, 791-92 (1974); see infra notes $41-48$ and accompanying text.

14 See Conrad v. State, 262 Ind. 446, 451, 317 N.E.2d 789, 792.

16 See Berge, supra note 8, at 238-41, 248-49; George, Extraterritorial Application of Penal Legislation, 64 Mich. L. Rzv. 609, 621-23 (1966); Levitt, supra note 8, at 331-32; Perkins, supra note 8, at 1163; Rotenberg, Extraterritorial Legislative Jurisdiction and the State Criminal Law, 38 Tex. L. Rev. 763, 773 (1960); Williams, Venue and the Ambit of Criminal Law (pt. 1), 81 LAw Q. Rsv. 276, 278-79 (1965).

16 See, e.g., The Schooner Exchange v. M'Faddon, 11 U.S. (7 Cranch) 116, 135 (1812); Berge, supra note 8, at 240-41; Levitt, supra note 8, at 328-29.

${ }_{17}$ See State v. Carter, 27 N.J.L. 499, 501-02 (Sup. Ct. 1859); Levitt, supra note 8, at 324-25. 
and easily applied in crimes of a purely local nature. However, in crimes which encompass acts and consequences in more than one state, the common law approach requires that the court localize the whole crime for jurisdictional purposes on one side of a political boundary line.

The method chosen by common law judges to localize a crime is to select a single point in space and time where it is said that the crime was "committed."18 This point, the "locus of the offense," determines jurisdiction over the offense and the offender. ${ }^{19}$ Courts identify the "locus of the offense" as the place where the "gist of the offense" occurred..$^{20}$ The "gist of the offense" is that element or those elements essential to demonstration of the existence of the crime-the gravamen of the offense or its most important aspect. ${ }^{21}$ Under this approach, mechanical and easily applied rules have been developed for ascertaining jurisdiction over a wide variety of interstate offenses. ${ }^{22}$

The traditional common law approach provides clear rules for resolving jurisdictional conflicts. It promotes the rule of law by en-

18 See Levitt, supra note 8, at 325; Perkins, supra note 8, at 1157-62; Williams, Venue and the Ambit of Criminal Law (pt. 3), 81 LAW Q. Rev. 518, 518-20 (1965).

19 See Levitt, supra note 8, at 324-25.

${ }^{20}$ Model Penal Code $\S 1.03$ comment at 3 (Tent. Draft No. 5, 1956); Levitt, supra note 8 , at 324 .

${ }^{21}$ See Levitt, supra note 8, at 333-38; Comment, Jurisdiction Over Interstate Homicides, 10 LA. L. REv. 87, 89 (1949).

32 For example, jurisdiction over a murder lay in the place where a defendant's act took effect without regard to the place where the act began or where the victim died. E.g., United States v. Davis, 25 F. Cas. 786, 787 (C.C.D. Mass. 1837) (No. 14,932) (Story, J.); Simpson v. State, 92 Ga. 41, 42, 17 S.E. 984, 985 (1893); State v. Gessert, 21 Minn. 369, 369-70 (1875); State v. Hall, 114 N.C. 909, 914-17, 19 S.E. 602, 603-04 (1894). Jurisdiction over robbery was held to lie where the property was taken from the victim rather than where force was first used. E.g., Sweat v. State, 90 Ga. 315, 323-24, 17 S.E. 273, 276 (1892). Jurisdiction over embezzlement lay where the trust was breached and the property converted without reference to where the property was taken or received. E.g., Bowen v. State, $206 \mathrm{Md}$. 368, 375-78, 111 A.2d 844, 847-48 (1955). Jurisdiction over bigamy lay where the second marriage ceremony took place without reference to the marital domicile of either marriage. E.g., State v. Stephens, 118 Me. 237, 107 A. 296 (1919); People v. Mosher, 2 Parker's Crim. R. 195, 196 (N.Y. O.\&T. 1855). Jurisdiction over forgery has been held to lie where the forged instrument is uttered or passed. E.g., Medley v. Warden of Md. House of Corrections, $210 \mathrm{Md}$. 649, 652, 123 A.2d 595, 596, cert. denied, 352 U.S. 858 (1956); State v. Hudson, 13 Mont. 112, 114, 32 P. 413, 414 (1893). But see Conley v. United States, 23 F.2d 226, 228 (4th Cir. 1928) (jurisdiction under federal law exists where the instrument is altered). Jurisdiction over libel has been held to attach where the defamatory statements were circulated rather than where they were written. E.g., Commonwealth v. Blanding, 20 Mass. (3 Pick.) 304, 311, 317 (1825); State v. Piver, 74 Wash. 96, 99, 132 P. 858, 859 (1913). Jurisdiction over larceny by false pretenses lay where the property was turned over rather than where the false pretenses were made. E.g., Connor v. State, 29 Fla. 455, 475, 10 So. 891, 891 (1892); Stewart v. Jessup, 51 Ind. 413, 415 (1875); People v. Adams, 3 Denio 190, 206 (N.Y. Sup. Ct. 1846). 
suring predictability and uniformity of result. Most importantly, it greatly simplifies the task facing courts confronted by challenges to their jurisdiction. Yet many courts find themselves dissatisfied with the results so rigid a system of rules dictates in particular cases. A court satisfied with the basic theory and approach of the common law model but dissatisfied with the result it yields in a particular case may stretch the common law through the use of legal fictions rather than reject it outright. In this way, the court can claim to adhere to the common law approach yet reach results unobtainable were its rules applied literally. ${ }^{23}$

Courts have employed a variety of legal fictions to establish the presence of the defendant or his offense in the state. The most straightforward fiction is constructive presence. As exemplified by Commonwealth $v$. Thomas, ${ }^{24}$ that fiction allows a court to declare a defendant who never entered a state constructively present by virtue of his participation in a conspiracy that led to an in-state death. ${ }^{25}$ A second fiction, new offense, applied only in larceny cases, permits a court to find that a new theft occurs when a thief crosses the state's border. ${ }^{26}$ Similarly, the fiction of a continuing offense extends the period in which an offense is considered to take

${ }^{28}$ This method was also employed in the area of conflicts of law. Mechanical rules allowing little room for flexibility were developed. When the rules proved too confining, courts developed various techniques such as renvoi, public policy, characterization, and substance/ procedure distinctions to achieve the desired results. See R. CRAmton, D. CurRIE \& H. KAY, Conplict of LAws 63-145 (3d ed. 1981).

24410 Pa. 160, 189 A.2d 255 (1963).

${ }^{25}$ See id. The defendant conspired with two others in Florida to commit a robbery in Pennsylvania, but remained in Florida while his accomplices went to Pennsylvania to commit the robbery. During the course of the robbery, the victim was killed. Jurisdiction over Thomas for felony-murder was held satisfied because "Thomas, as a conspirator, was constructively present when the robbery and the homicide occurred." Id. at 166, $189 \mathrm{A.2 \textrm {d }}$ at 258-59. See also State v. Chapin, 17 Ark. 561, 565-66 (1856) (while principal may be constructively present wherever his acts take effect, accessory before the fact is indictable only in the state where he became an accessory); Simpson v. State, 92 Ga. 41, 46, 17 S.E. 984, 985 (1893) (defendant who, while in one state, shot at the victim across the border held to have been constructively present in the victim's state through the agency of the bullet); Johns v. State, 19 Ind. 421, 428-29 (1862) (same); State v. Wyckoff, 31 N.J.L. 65, 69 (Sup. Ct. 1864) (accessory deemed constructively present where principal committed acts); State v. Winckler, 260 N.W.2d 356, 361 (S.D. 1977) (fear created by defendant's acts in Indian territory but experienced by victims in state held to render the defendant constructively present where the fear was felt).

26 State v. Underwood, $49 \mathrm{Me} .181,182-83$ (1858); Worthington v. State, $58 \mathrm{Md} .403$, 409 (1882). The court in each case argued that asportation of stolen goods into the forum state constitutes a "new offense." See, e.g., Worthington, $58 \mathrm{Md}$. at 409-10. Although the other elements of larceny are lacking, they are imputed to the defendant by a questionable analogy to the case of one thief stealing from another, in which both are deemed to have stolen from the owner of the goods. See, e.g., Underwood, $49 \mathrm{Me}$. at 183. 
place to include time spent by the defendant in the state seeking jurisdiction. ${ }^{27}$ Other courts dissatisfied with the results dictated by a strict application of the common law rule have resorted to reinterpreting offenses of commission as offenses of omission in order to obtain jurisdiction. ${ }^{28}$ The prevalence of such fictions, combined with the essentially untrammeled discretion that attends their use, ${ }^{29}$ largely undercuts the clarity and predictability that are the chief virtues of the common law rule. ${ }^{30}$

\section{B. Modern Statutes and the Requirement of a Jurisdictionally Significant Threshold of Activity}

The late nineteenth and early twentieth centuries witnessed a flurry of legislative activity as states began to replace the common law with statutes defining the territorial scope of their criminal laws. ${ }^{31}$ These statutes typically eliminated the common law rule

27 The fiction that an offense continues has been applied to a variety of crimes. See, e.g., Newlon v. Bennett, 253 Iowa 555, 112 N.W.2d 884, cert. denied, 369 U.S. 658 (1962) (receiving stolen goods); Commonwealth v. Macloon, 101 Mass. 1 (1869), overruled, Commonwealth v. Lewis, 381 Mass. 411, 409 N.E.2d 771, cert. denied, 450 U.S. 929 (1981) (homicide); Commonwealth v. Blanding, 20 Mass. (3 Pick.) 304 (1825) (libel). The continuingoffense fiction is ordinarily used where a single element of an offense occurs in the forum state after all the other elements have occurred elsewhere. See, e.g., Macloon, 101 Mass. at 7 (homicide continues in the state where the victim dies although the fatal blow was struck elsewhere); Blanding, 20 Mass. (3 Pick.) at 311, 317 (the offense of publishing a libel is committed in any state in which the libel is circulated).

The question in these cases is typically one of statutory interpretation: the courts examine the substantive offense to determine if it is of a type which can be deemed to be continuing. See United States v. Lombardo, 241 U.S. 73, 76-79 (1916); State v. Pambianchi, 139 Conn. 543, 547, 95 A.2d 695, 697 (1953). However, the result of this question of substantive law may depend upon the court's view of the jurisdictional question. Compare Macloon, 101 Mass. at 7 (homicide continues until the victim dies) with Ex parte McNeeley, $36 \mathrm{~W}$. Va. 84, 93, 14 S.E. 436, 439 (1892) (opposite result because the accused should not be subjected to law of any state into which his victim should choose to wander).

${ }^{28}$ For example, in State v. Scofield, 7 Ariz. App. 307, 438 P.2d 776 (1968), defendant rented a car in Arizona and took it to Texas where he converted it to his own use. He was convicted in Arizona under an embezzlement statute. The court rejected defendant's challenge to its jurisdiction, explaining: "In this case, the legislature has carefully selected as the actus reus the failure to return the leased chattel thus clearly selecting something which negatively occurred only in this state." Id. at 315,438 P.2d at 784 (footnote omitted); see also Poindexter v. State, 137 Tenn. 386, 396, 193 S.W. 126, 129 (1916) (holding that the intent of a Tennessee statute making criminal the failure to support a child was to punish neglectful parents in order to deter neglect and protect the abandoned families and thus venue of offenses lay in the county where a guilty parent resided).

29 Compare Commonwealth v. Macloon, 101 Mass. 1 (1869) (continuing offense fiction applies to homicide) with Ex Parte McNeeley, 36 W. Va. 84, 93-94, 14 S.E. 436, 439-40 (1892) (contra).

${ }^{\text {so }}$ See infra notes 71-74 and accompanying text.

s1 These statutes are collected and analyzed by Berge, supra note 8, at 253-59. 
that only the state in which the "gist of an offense" occurred could exercise jurisdiction. Instead they permitted an exercise of jurisdiction by any state in which a sufficiently significant part of the crime had been committed. ${ }^{32}$ Under these statutes, the courts were left with the task of defining what constitutes a jurisdictionally sufficient level of criminal activity. ${ }^{33}$

The most famous opinion addressing the appropriate level of activity for an assertion of jurisdiction under such a statute is Judge Cardozo's in People v. Werblow. ${ }^{34}$ In that case, the defendant and his two brothers were convicted of grand larceny by false pretenses. The three brothers had conspired in New York to defraud the London branch of a New York bank. Acts in furtherance of the conspiracy had been performed in New York, but all of the elements of the crime of larceny by false pretenses had occurred in England. Nine years earlier, the New York Court of Appeals had construed the New York statute governing criminal jurisdiction ${ }^{35}$ to require a New York court asserting jurisdiction to find that the defendant committed at least one of the constituent elements of the substantive offense in New York. ${ }^{36}$ Rather than deny jurisdiction on the ground that none of the constituent elements of larceny occurred in New York, ${ }^{37}$ Judge Cardozo chose to interpret the statute in a new way:

We think a crime is not committed either wholly or partly in this State unless the act within this State is so related to the crime that if nothing more had followed, it would amount to attempt. We do not mean that this construction of the statute is the consequence of some inherent limitation upon the

s2 See id. at 248-59. Some examples of such statutes are: ARIz. Rev. STAT. ANN. $\$ 25$ (1913) (current version codified at ARIz. Rev. Stat. AnN. § 13-168 (1978)); Cal. Penal Code $\S \S 778,778(a)$ (West 1970); MinN. Gen. Stat. § 9909 (1923) (repealed 1979); N.D. CoMp. LAws $\$ 9206$ (1913) (current version codified at N.D. CENT. CODE § 29-03-01 (1974)); N.Y. Consol. Laws § 1930(1) (Birdseye, Cummings \& Gilbert 1909) (repealed 1965); OKLA. Comp. STAT. § 1510 (1921) (current version codified at OKLA. STAT. tit. 22, §§ 121-128 (1969)); UTAH Comp. Laws § 7916 (1917) (current version codified at UTAH Code ANN. § 76-1-201 (1978)); Wash. Comp. Stat. § 2254 (Remington 1922) (current version codified at WaSh. REv. Code $\S \S 10.25 .010-10.25-050$ (1974)); WIS. STAT. ch. 188, § 4635a (1919) (current version codified at Wis. STAT. \$ 939.03 (1981)).

ss The "sufficiency of activity" approach is not limited to cases decided under statutes, but has also been employed by courts deciding, under the common law rule, whether a crime was committed within their state. See, e.g., State v. Reldan, 166 N.J. Super. 562, 567, 400 A.2d 138, 141 (Law Div. 1979).

34 241 N.Y. 55, 148 N.E. 786 (1925).

ss N.Y. Penal Law § 1930(1) (Consol. 1925) (repealed 1965).

${ }^{36}$ People v. Zayas, 217 N.Y. 78, 81-83, 111 N.E. 465, 465-66 (1916).

37 Cardozo rejected this resolution of the case. 241 N.Y. at 60,148 N.E. at 788-89. 
power of the legislature. We assume that the legislature may fix the beginning of the crime at a point earlier than attempt, and identify it with the initial stages of combination or incitement or preparation. The question is whether by this statute it had any thought of effecting a change so revolutionary. ${ }^{38}$

Cardozo concluded that the legislature did not and hence that the trial court had asserted jurisdiction improperly. Largely as a result of Cardozo's opinion in Werblow, ${ }^{39}$ the prevailing interpretation of statutes permitting jurisdiction to be exercised where a significant level of criminal activity has occurred has been to set the threshold of significance at the level of attempt. ${ }^{40}$

\section{The Integral Relation Approach}

The Indiana courts have developed a separate approach to criminal jurisdiction of which the central notion is the degree of relation between the defendant's in-state acts and the acts constituting the crime with which he is charged. The leading case in the development of this approach is Conrad $v$. State. ${ }^{41}$

In Conrad, the defendant fought with the victim and rendered him unconscious in Indiana, put him in the trunk of a car, drove into Ohio, and "beat his brains out."42 The defendant appealed the Indiana murder conviction on jurisdictional grounds. Indiana had no applicable jurisdictional statute. ${ }^{43}$ The trial judge had instructed the jury that in order for Indiana to have jurisdiction, the jury must find that the killing was

part of a common plan, design, and intent to kidnap and kill . . . which originated and commenced in Wayne County, Indi-

ss Id. (emphasis added). Interestingly, Judge Cardozo cited no legislative history or other authority in support of his conclusion.

39 Some courts had adopted the attempt standard prior to Werblow. See, e.g., People v. Botkin, 132 Cal. 231, 233, 64 P. 286, 287 (1901); see also Green v. State, 66 Ala. 40, 44-45 (1880) (holding that partial commission within the state does not establish jurisdiction unless "what is done in the [state] which takes jurisdiction, is a substantial act of wrong, and not merely some incidental thing, innocent in itself alone" (citation omitted)).

10 See, e.g., People v. Buffum, 40 Cal. 2d 709, 716, 256 P.2d 317, 320 (1953); People v. Utter, 24 Cal. App. 3d 535, 550, 101 Cal. Rptr. 214, 224 (1972); People v. Holt, 91 III. 2d 480, 489, 440 N.E.2d 102, 106 (1982); State v. Harrington, 128 Vt. 242, 250, 260 A.2d 692, 697 (1969); see also Model Penal Code $§ 1.03$ comment at 8-10 (Tent. Draft No. 5, 1956); Rotenberg, supra note 15, at 777-79.

4262 Ind. 446 , 317 N.E.2d 789 (1974).

42 Id. at 448,317 N.E.2d at 790.

43 Indiana's extraterritorial jurisdiction statute, IND. CoDE § 35-1-2-3 (1976) (amended and recodified at IND. CODE $\S 35-41-1-1$ (1977)), related only to crimes commenced outside the state and consummated within it. 
ana, ... . and that [the killing] was . . . the result of one continuing course of action by the defendant, [and not] a separate and independent set of acts occurring outside of the State .....44

On appeal, these instructions were approved and the conviction affirmed; the court explained that " $[t]$ here was substantial evidence presented from which the jury could find that the assault and abduction of the victim were integrally related to the victim's murder. Thus viewed, the assault and abduction provide an adequate jurisdictional base for appellant's conviction ....."45

The integral relation approach is not yet well developed. It has been employed in only one case since Conrad, and this case shared a virtually identical fact pattern. ${ }^{46}$ No court in any other state appears to have followed the Indiana initiative. In effect, the integral relation approach appears to be no more than the reverse of the continuing offense fiction. The former allows the courts of one state to assert jurisdiction over acts which occurred in a second state subsequent to the acts that occurred in the first state. The latter allows the courts of the first state to assert jurisdiction over acts which occurred in the second-state prior to the acts which occurred in the first state. ${ }^{47}$ The justification for both seems to be that a planned sequence of acts culminating in a crime should not be severed arbitrarily at the point where the defendant happens to cross a jurisdictional boundary. ${ }^{48}$

\section{Critique of Existing Approaches in Resolving Questions} OF JURISDICTION Over INTERSTATE FeLONY MURDERS

\section{A. The Common Law Approach}

The traditional common law approach is primarily a means to the end of developing mechanically applied rules conferring jurisdiction on a single state. ${ }^{49}$ Although there is no generally accepted common law rule for determining jurisdiction over an interstate felony murder, ${ }^{80}$ such a rule might readily be developed under the

14262 Ind. at 450,317 N.E.2d at 791 (emphasis omitted).

4s Id. at 451,317 N.E.2d at 792.

16 Pollard v. State, 270 Ind. 599, 388 N.E.2d 496 (1979).

17 See supra note 27.

4see Conrad, 262 Ind. at $450-51,317$ N.E.2d at 791-92.

40 See supra notes 15-22 and accompanying text.

so Although State v. Reldan, 166 N.J. Super. 562, 400 A.2d 138 (Law Div. 1979), holds that, under common law, commission of the felony is sufficient to confer jurisdiction over a felony murder in which the death occurred elsewhere, the court's opinion relies on a statu- 
common law "gist of the offense" approach. To devise a common law jurisdictional rule for felony murder, courts need only choose what they consider to be the most significant element of the crime as the peg upon which to hang jurisdiction. Since felony murder is a species of homicide, ${ }^{51}$ courts may be expected to apply the common law rule for homicide, ${ }^{52}$ and establish jurisdiction in the place where the fatal stroke was delivered. ${ }^{53}$ This rule is clear, easily applied, administratively convenient, and yields uniform results in interstate cases. If these pragmatic values were the sole concern in formulating jurisdictional rules, the common law rule would have much to commend it. Judged exclusively by such standards, however, a still better rule would provide that all homicides be tried in Alaska. ${ }^{54}$ This rule would be the pragmatic superior of any common law rule, for it would relieve the courts of having to make any determinations beyond the fact that a homicide occurred..$^{55}$

Such a rule seems clearly unacceptable, and rightly so. It is unacceptable because in evaluating any system of rules it is neces-

tory principle rather than common law reasoning. See supra note 8. People v. Holt, $91 \mathrm{Il}$. $2 d 480,440$ N.E.2d 102 (1982), on the other hand, invokes common law reasoning to conclude that jurisdiction exists only in the state where the death occurred, see supra notes 10 12 and accompanying text, though the court's decision was made under statutory authority, see supra text accompanying notes 4-7.

11 See Regina v. Serné, 16 Cox Crim. Cas. 311, 312 (Central Criminal Court 1887).

${ }^{52}$ The analysis in People v. Holt, 91 IIl. 2d 480, 440 N.E.2d 102 (1982), follows this pattern.

Bs See supra note 22 . In a few states, an early English statute, $2 \& 3 \mathrm{Edw} .6$, ch. 24 (1548), which replaced the place-of-the-stroke rule with a place-of-death rule, was held to have been incorporated into the common law of the state. See, e.g., State v. McCoy, 8 Rob. 545, 547-48 (La. 1844). These states, however, are clearly in the minority. See United States v. Guiteau, 12 D.C. (1 Mackey) 498, 538-45 (1882); Commonwealth v. Apkins, $148 \mathrm{Ky} .207$, 212, 146 S.W. 431, 434 (1912); State v. Carter, 27 N.J.L. 499, 500 (Sup. Ct. 1859); State v. Justus, 65 N.M. 195, 199, 334 P.2d 1104, 1106-07 (1959); Moran v. Territory, 14 Okla. 544, 549-54, 78 P. 111, 114-15 (1904); cases cited supra note 22.

s4 B. Currie, Conflict, Crisis and Confusion in New York, in Selected Essays on the CoNFLICT of LAwS 690, 699-701 (1963) (arguing that if only pragmatic concerns are at issue in the choice of a rule for resolving choice of law in wrongful death actions, all actions should be referred to the law of Alaska); Sunstein, Section 1983 and the Private Enforcement of Federal Law, 49 U. CHI. L. REv. 394, 436-38 (1982) (rejecting the need for per se rules in the face of concerns other than clarity and ease of administration).

ss Determining the place of death or of the felony can be quite difficult. It may be unclear whether the victim was killed where the body is found or killed elsewhere and the body then brought into the state. See, e.g., State v. Reldan, 166 N.J. Super. 562, 569-70, 400 A.2d 138, 141-42 (Law Div. 1979). In other cases, it may be unclear what caused the victim's death although the sequence of events is known. See, e.g., United States v. Parker, 622 F.2d 298, 299-300 (8th Cir.), cert. denied, 449 U.S. 851 (1980). A rule requiring that all homicide cases be tried in Alaska would call for no more than a showing that a homicide occurred. To the extent that ease of administration is the sole concern, it would seem to be the preferable rule. 
sary to consider not only the ease with which the rule can be administered but also the consistency between the results the rule dictates and the rule's theoretical underpinnings. ${ }^{.6}$

The theoretical underpinning of the common law approach is the assertion that jurisdiction is solely an expression of sovereign interests. ${ }^{\text {s7 }}$ The common law approach regards the interests of a sovereign as circumscribed by its territorial limits and, as a corollary, as exclusive and absolute within those limits. ${ }^{58}$ However, as Brainerd Currie cogently demonstrated in the field of conflicts of law, territorial boundaries and sovereign state interests are not necessarily coextensive. ${ }^{59}$ This same observation holds true for criminal law. While territorial occurrence may virtually always raise a state interest, extraterritorial occurrence does not necessarily preclude one. For instance, it has long been recognized that acts committed in a place where they are perfectly legal may be punished in a place where they are not if they have consequences in that place. ${ }^{60}$ Moreover, it cannot be asserted with certainty that

se See Epstein, The Principles of Environmental Protection: The Case of Superfund, 2 Cato J. 9, 12-14 (1982). Professor Epstein speaks of this problem in terms of a tension between the validity of a rule, the extent to which it embodies correctly normative principles, and the reliability of the rule, the percentage of cases in which it produces a correct result based upon those principles.

"7 See The Schooner Exchange v. M'Faddon, 11 U:S (7 Cranch) 116, 135 (1812) ("The jurisdiction of courts is a branch of that which is possessed by the nation as an independent sovereign power."); Restatement of Conflict of LAwS § 42 (1934) (" jurisdiction' means the power of a state to create interests which . . . will be recognized as valid in other states"); Berge, supra note 8, at 240-41; Levitt, supra note 8, at 328-29.

s.

The jurisdiction of the nation within its own territory is necessarily exclusive and absolute. It is susceptible of no limitation not imposed by itself. Any restriction upon it, deriving validity from an external source, would imply a diminution of its sovereignty to the extent of the restriction, and an investment of that sovereignty to the same extent in that power which could impose such restriction.

The Schooner Exchange v. M'Faddon, 11 U.S. (7 Cranch) 116, 135 (1812); see REstatement of Conflict of LAws § 1 comment a, § 425 (1934); sources cited infra note 62 . The development of common law jurisdictional rules primarily along the lines of territorial principles has been traced to historical factors peculiar to England. See Levitt, supra note 8, at 325-29 (arguing that the common law's emphasis on territoriality was the result of historical, religious, and metaphysical tendencies among ancient Britons); Perkins, supra note 8, at 1157 (arguing that the common law was concerned with territoriality "because the beginning of our criminal justice system in the troublous days of the dawn of civilization in the British Isles was concerned so exclusively with the problem of keeping the peace"); Williams, supra note 15, at 276 (arguing that the common law emphasis on territoriality developed as a result of the early requirement that the jury be summoned from the locality where the crime had occurred so that jurors could speak of their own knowledge).

s" See B. CurrII, Married Women's Contracts: A Study in Conflicts-of-Laws Method, in B. CurRIE, supra note 54, at 77.

so See Strassheim v. Daily, 221 U.S. 280, 284-85 (1911); Dealy v. United States, 152 
in every case only one sovereign's interest will have been injured.

The rules formulated under the common law approach are devised only with territorial interests in mind. ${ }^{61}$ Even if the common law method is successful in protecting those interests, ${ }^{62}$ to the extent that sovereign interests extend beyond territoriality, the common law jurisdictional rules fail to realize completely the purpose for which they are created-protecting sovereign interests generally. While the pragmatic values of the common law rule are not insignificant, ${ }^{63}$ an approach that preserves these pragmatic advantages but does not suffer from an inconsistency between justification and result would be preferable.

In addition to the failure of the common law rule to fulfill its purpose, the common law method for developing jurisdictional rules is too arbitrary to produce rules that effectively protect sovereign interests even when these rules are narrowly defined in terms of territoriality. The common law method proceeds by reducing a crime to a single essential element or gist of an offense. ${ }^{84}$ The state where the gist of the offense is said to occur, and only that state, ${ }^{68}$ may assert jurisdiction..$^{68}$ As a simple matter of definition, there is some doubt whether it can accurately be said that a crime is committed when a single element occurs. The gist of an offense is defined as that element of the offense without which it cannot be said the crime has been committed. ${ }^{67}$ Yet this statement can be made about every element of an offense; unless all elements of a given offense have occured, the crime has not been committed. For example, the gist of larceny by false pretenses is said to be the turning over of the property. ${ }^{68}$ While it is true that larceny by false

U.S. 539, 546-47 (1894); State v. Chapin, 17 Ark. 561, 565-66 (1856); see also Hanks v. State, 13 Tex. Crim. 289 (1882) (under Texas jurisdictional statute, forgery committed entirely in Louisiana can be prosecuted in Texas because Texas property was the object of the forgery).

B1 It is important to recognize that the common law did not acknowledge interests derived from sources other than territoriality and then choose to limit itself to territorial interests. Rather, in the eyes of common law judges, sovereign interest and territoriality were one and the same. See J. Story, Commentaries on the Conflicts of Laws §§ 18-23 (1st ed. Boston 1834); Lorenzen, Story's Commentaries on the Conflicts of Laws-One Hundred Years After, 48 HARv. L. REv. 15, 34-35 (1934).

${ }^{62}$ An assumption the validity of which is by no means clear. See infra notes 64-69 and accompanying text.

6s See supra text accompanying notes 51-55.

64 See supra notes 18-21 and accompanying text.

es See, e.g., State v. Carter, 27 N.J.L. 499, 501-02 (Sup. Ct. 1859); Moder Penal Code § 1.03 comment at 3 (Tent. Draft No. 5, 1956).

${ }^{66}$ Levitt, supra note 8 , at 324-25.

67 See supra note 21 and accompanying text.

${ }^{6 s}$ See Stewart v. Jessup, 51 Ind. 413, 415 (1875). 
pretenses is not committed unless property is turned over, neither is it committed without the making of false pretenses. Similarly, while there can be no felony murder without the death, neither can there be a felony murder without the felony. Courts which adopt the common law approach reason as if there were something fundamental in certain links in the chain of criminal acts which draws exclusive jurisdiction of the whole crime to the place where those links occurred. Yet these courts are unable to offer any justification for their choice of a particular link beyond the bare assertion that they feel that link to be more important. ${ }^{69}$

There is, moreover, a more fundamental flaw in the logic that equates the time of commission with the occurrence of a particular element. Glanville Williams explains:

It would be logical to assert that a crime is fully consummated when and only when the last necessary element takes place, because a denial of this proposition would involve a self-contradiction. But the time of consummation is not necessarily the same as the time of commission. The word "commission" naturally refers to the defendant's physical act . . . . ${ }^{70}$

The term commission refers to all of the defendant's acts; from its initiation until its consummation, a crime is being committed, and an approach that simply picks a point on the line and claims that point to be the point of commission is logically spurious.

Modifying the common law though the use of legal fictions cannot remedy the situation. Legal fictions permit results that are unobtainable through literal application of a rule while preserving the "symmetry of general theory;" they do not make the theory any more rational. Legal fictions do, however, hinder precise analy$\operatorname{sis}^{72}$ and lead to further results that are justifiable only on the strength of the fictions..$^{73}$ Furthermore, the practical benefits of a fixed rule, uniformity of result and ease of application, are diminished by use of the fictions, which are largely discretionary tools at the disposal of the court. ${ }^{74}$ While modification of the common law

-o See, e.g., cases cited supra note 22.

70 Williams, supra note 18 , at 520-21.

7 See Hyde v. United States, 225 U.S. 347, 386 (1912) (Holmes, J., dissenting).

72 Id.

78 See, e.g., Commonwealth v. Macloon, 101 Mass. 1, 8 (1869) (applying the continuingoffense fiction to homicide); Berge, supra note 8, at 244-48; supra note 27.

74 Compare Commonwealth v. Macloon, 101 Mass. 1, 8 (1869) (homicide continues until the victim dies) with Ex parte McNeeley, 36 W. Va. 84, 93, 14 S.E. 436, 439 (1892) (continuous offense fiction not applicable to homicide). 
approach through the use of legal fictions does not contribute to making it more rational, it does result in the forfeiture of the pragmatic values that are the approach's chief virtues.

The common law approach fulfills its theoretical purpose, the protection of sovereign interests, only by first limiting those interests to territoriality, and then by characterizing an offense as having been committed only in the place in which the gist of the offense occurs. So long as all elements of an offense occur within one state, these simplifying assumptions about sovereign interests and the place of occurrence do not lead to a disparity between the result under the common law rule and the purpose of the rule, protecting state interests. For entirely intrastate offenses, these assumptions need not be subjected to critical scrutiny.

In cases of interstate crime, however, these assumptions become vital links in the theoretical justification of the common law result. Such offenses cannot be characterized logically as having been committed only in the place where the gist of the offense occurred, and sovereign interests cannot be confined within political borders. Under the common law rule as applied to interstate offenses, the interests of states other than the one in which the gist of the offense occurred are simply subordinated. Yet there is no necessary link between sovereign interests and the "gist of the offense" that should operate to the exclusion of other aspects of the crime. Rather than attempt to modify the common law rule by the use of legal fictions that do little but erode the common law rule's practical virtues, courts and legislatures should abandon the common law approach in favor of a rule that better serves the sovereign interests that support jurisdiction in general.

\section{B. Modern Approaches: Threshold of Activity and Integral Relation}

The modern approaches to criminal jurisdiction-“"sufficiency of activity" and "integral relation"-do not provide a satisfactory means of devising a rule to resolve jurisdictional disputes over interstate felony murders for two reasons. First, by virtue of the peculiar nature of felony murder as a constructive intent crime, these approaches are simply inapplicable to jurisdiction over felony murder. Second, and more generally, proponents of the modern approaches have failed to elicit a theory of the purposes of jurisdiction by which the rules that they have developed can be judged.

As noted above, almost every court that has adopted a "sufficiency of activity" approach to the problem of criminal jurisdiction over interstate offenses has chosen the attempt standard as the 
threshold of jurisdictional significance. ${ }^{75}$ The attempt standard, unfortunately, is of no aid in resolving the problem of jurisdiction over interstate felony murder since, by definition, there cannot be an attempted felony murder. ${ }^{76} \mathrm{~A}$ court that has adopted the attempt standard will be forced back to the common law mode of analysis since the attempt standard is necessarily inapplicable to felony murder. ${ }^{77}$

The attempt standard is merely one possible implementation of the "sufficiency of activity" approach to criminal jurisdiction. Although the attempt standard is inapplicable to felony murder, the question remains whether the "sufficiency of activity" approach is itself a desirable one for devising a rule for jurisdiction over interstate felony murders. For instance, it might be argued that jurisdiction should attach if the defendant prepares within the state to commit an offense, or perhaps "significant activity" or some other level of conduct should be the touchstone for an assertion of jurisdiction.

Merely to suggest these possibilities reveals the essental diffculty with the "sufficiency of activity" approach. Choosing a threshold is easy; justifying it on analytically solid grounds is another matter altogether. ${ }^{78}$ In the absence of some articulable stan-

73 See supra note 40 and accompanying text.

${ }^{76}$ Felony murder involves an accidental killing or a killing where no specific intent can be proved. One must intend to do something in order to attempt it. Hence, by definition, a felony murder cannot be attempted.

77 This shortcoming may account for the decision of the court in People v. Holt, $91 \mathrm{III}$. $2 d 480,440$ N.E.2d 102 (1982). The decision is confusing because it blends two analytically distinct modes of thinking about criminal jurisdiction: the common law gist of the offense approach, see id. at 484-87, 440 N.E.2d at 104-05, and the sufficiency of activity approach, see $i d$. at $488-89,440$ N.E.2d at 106 . It seems likely that the court, faced with an inapplicable standard, and compelled to provide some rationale, chose to use an analysis to which it was accustomed: the common law analysis. However, since the decision was rendered under a statute defining partial commission in terms of elements of the offense, Criminal Code of 1961 § 1-5, IlL. REv. STaT. ch. 38, § 1-5 (1981), the court's analysis is intertwined with statutory concepts of jurisdiction. The dissent argues that since the attempt standard is not applicable, the court should abandon it and apply the statute in a straightforward fashion: a felony is an element of felony murder, hence Illinois can assert its jurisdiction. Holt, $91 \mathrm{~m}$. 2d at 498-99, 501, 440 N.E.2d at 110-11, 112 (Moran, J., dissenting). Rather than modifying or abandoning the attempt standard, however, the court offers a rather abstruse analysis, reserving the option of defining the jurisdictionally sufficient level of activity as something less than an attempt. Id. at 489,440 N.E.2d at 106.

${ }^{78}$ For example, one court held that commission of a felony within the state is adequate for asserting jurisdiction over an interstate felony murder without explaining why this result is justified. State v. Reldan, 166 N.J. Super. 562, 400 A.2d 138 (Law Div. 1979); cf. Lane v. State, 388 So. 2d 1022 (Fla. 1980) (per curiam) (defendant's attempt to rob the victim in forum state sufficient to confer jurisdiction over premeditated murder culminating elsewhere). 
dard for defining the act or acts which constitute sufficient grounds for jurisdiction, the "sufficiency of activity" approach has little to offer to the development, on a principled basis, of a rule for jurisdiction over interstate felony murders. ${ }^{79}$

Similarly, the "integral relation" approach, with its reliance on the in-state formulation of a "common plan, design, and intent" to commit the crime consummated outside the state, ${ }^{80}$ seems inapplicable to felony murder. The instructions approved by the court in Conrad specifically provided that Indiana would not have jurisdiction if the kidnapping committed within its borders were committed without any intention to kill the victim. ${ }^{81}$ Because a felony murder does not involve any specific intent to kill, it would be impossible to find that the killing was part of an existing "continuous plan, design and intent" when the felony was committed.

Like the "sufficiency of activity" approach, the "integral relation" approach is open to the criticism that, though it purports to provide a method for developing a rule to determine jurisdiction, it does not explain the theoretical premises that underlie that method. It is, therefore, impossible to evaluate the ultimate desirability of any rules formulated under either approach.

This last flaw is one that all of the currently existing alternatives share to some extent. While it may be true that some of the current approaches to criminal jurisdiction will yield a rule for felony murder, the real question is whether any will yield a rational rule. A rational rule is one which reflects the theoretical justifications that call it into existence. Generally speaking, jurisdictional

79 For example, the attempt threshold is justified on the basis of the substantive liability which arises once the level of an attempt is reached. See Rotenberg, supra note 15, at 778. It is not clear, however, that the standard for substantive liability is a proper basis upon which to justify a minimum threshold for the assertion of jurisdiction. With regard to a purely local offense, the state can neither exert jurisdiction nor punish someone until the level of mere preparation is passed and the level of attempt is reached. See W. LAFAvE \& A. ScotT, Handbook of Criminal Law 431 (1972). Conduct less than an attempt, such as preparation, is not subject to punishment. However, this fact does not necessarily mean that such conduct is without jurisdictional significance; there is simply no offense over which jurisdiction can be asserted until the threshold of attempt is crossed. In this sense, preparation that does not culminate in a crime, and hence is not punishable, is different from preparation that does result in the commission of a crime in another state. See Rotenberg, supra note 15, at 778-79. While it is true that the accused cannot be punished until at least an attempt is committed, it does not necessarily follow that once the ultimate crime has occurred this same level must define the jurisdictional threshold. The attempt standard presumes the identity of a state's interests for purposes of jurisdiction and of liability with. out ever addressing the issue of what these interests are.

${ }^{80}$ See supra notes $41-48$ and accompanying text.

${ }^{81}$ Conrad v. State, 262 Ind. 446, 450, 317 N.E.2d 789, 791 (1974). 
rules are intended to protect the interests of sovereigns. ${ }^{\mathbf{8 2}}$ The common law approach will inevitably slight some sovereign interests in cases of interstate felonies. ${ }^{83}$ While the same is not inevitably true of the other approaches, it is difficult to see any necessary theoretical connection between the extent of in-state activity or the in-state formulation of a criminal plan and the implication of sovereign interests that would justify the boundaries of either rule. To develop a rational rule, it is necessary to ascertain in detail the sovereign interests protected by criminal jurisdiction, and, in particular, by jurisdiction over felony murder.

\section{Analysis of the Law of Criminal Jurisdiction}

\section{A. International Principles of Criminal Jurisdiction}

The development of the law of criminal jurisdiction in England and the United States has for so long proceeded under the approaches described above that it is difficult to find clear statements of what the goals of jurisdictional law are. However, by examining criminal jurisdiction in international law, one can obtain a broad view of the central precepts of the law of jurisdiction. Since the same inquiry is involved in both the international and the interstate contexts, i.e., how to weigh the competing interests of several sovereign states, it is legitimate to apply the precepts derived from international law to the problems of jurisdiction over interstate crimes.

There are five general principles upon which nations base claims of criminal jurisdiction. ${ }^{84}$ The first is the territorial principle, which determines jurisdiction by reference to the place where the offense is committed. ${ }^{85}$ Territoriality is the most commonly accepted theory for jurisdiction ${ }^{88}$ and is a logical outgrowth of the conception of law enforcement as a means of keeping the peace. ${ }^{87}$ The second is the nationality principle, which determines jurisdiction by reference to the nationality of the person committing the

s2 See supra note 57 and accompanying text.

ss See supra notes 61-69 and accompanying text.

84 See United States v. Rodriguez, 182 F. Supp. 479, 487 (S.D. Cal. 1960), rev'd on other grounds sub nom. Rocha v. United States, 288 F.2d 545 (9th Cir. 1961); Codification of International Law, 29 AM. J. INT'L L. 1, 443, 445 (Supp. 1935) [hereinafter cited as Codification]; George, supra note 15, at 613-14; Perkins, supra note 8, at 1155-56.

ss See Codification, supra note 84, at 445.

se Restatement of the Foreign Relations Law of the United States (Revised) § 402 comment a (Tent. Draft No. 2, 1981) [hereinafter cited as REsTatemENT].

${ }^{87}$ See Perkins, supra note 8, at 1155. 
offense. ${ }^{88}$ The nationality principle is derived from the ancient conception of law enforcement as a means of disciplining members of the tribe or clan, ${ }^{89}$ but its continued use has been justified on the basis of the state's power to regulate its own internal affairs.90 The degree to which this approach has been accepted varies considerably among jurisdictions.91 The third is the protective principle, which determines jurisdiction by reference to the national interest injured by the offense. ${ }^{22}$ The fourth, closely related to the third, ${ }^{93}$ is the so-called passive personality principle, which determines jurisdiction by reference to the nationality or national origin of the person injured by the offense..$^{94}$ Both the protective and passive personality principles emphasize the effect of the crime, conferring jurisdiction on a state that suffers the consequences of a criminal act wherever committed. ${ }^{95}$ The fifth is the universality principle, which confers jurisdiction on the state that first obtains custody of the offender. ${ }^{98}$ This principle has been applied only to the crime of piracy, which is deemed to be a crime against all nations. ${ }^{97}$ Taken together, these five principles recognize two classes of sovereign interests that will support jurisdiction: (1) a state's interest in regulating conduct within its territory, regardless of where its consequences are felt; and (2) a state's interest in protecting itself and its citizens from the harmful consequences of acts wherever perpetrated..$^{98}$ Under each of these principles, jurisdiction over an offense rests on some effect caused by the offense on the interests of the sovereign seeking to impose jurisdiction. In other

8s Codification, supra note 84 , at $\mathbf{4 4 5}$.

89 See Perkins, supra note 8, at 1155.

0 State ex rel. Chandlex v. Main, 16 Wis. 398, 412-13 (1863).

91 "[T]here are striking differences in the extent to which [the nationality theory] is used in the different national systems." Codification, supra note 84, at 445 . Because the nationality theory can be characterized as a denial of the efficacy and legitimacy of the laws of other states, its applicability in an interstate context is questionable under the full faith and credit clause, U.S. ConsT. art. IV, § 1. See Magnolia Petroleum Co. v. Hunt, 320 U.S. 430,439 (1943). The nationality principle has been employed only rarely in the United States, and then only in cases where a citizen's acts affect the forum state because of his citizenship. See, e.g., State ex rel. Chandler v. Main, 16 Wis. at 412-13 (upholding the validity of a statute imposing criminal sanctions on absentee voters for voter irregularities).

92 Codification, supra note 84 , at 445 .

${ }^{3} \mathrm{Id}$.

24 Id. Perkins, supra note 8 , at 1155 n.1, contends that the passive personality principle is merely a subcategory of the protective principle.

28 Perkins, supra note 8, at 1155; see Hanks v. State, 13 Tex. Crim. 289, 309 (1882).

Codification, supra note 84, at 445 .

97 Perkins, supra note 8, at 1155-56.

${ }^{8}$ See Restatement, supra note 86, \$§ 401-403. 
words, as the common law recognized, ${ }^{99}$ questions of jurisdiction are merely questions of whether a given nation's sovereign interests have been affected. ${ }^{100}$

\section{B. State Interests and the Development of Rules for Criminal Jurisdiction}

To say that the law of criminal jurisdiction has as its purpose the protection of state interests does not answer the question of how rules that serve this purpose may be developed. The common law approach, which also purports to protect state interests, was rejected above because the rules it developed protect only territorial interests. ${ }^{101}$ The essential problem in devising rules for criminal jurisdiction is accommodating state interests within a framework that is both comprehensive and comprehensible. ${ }^{102}$

Existing law offers several approaches to this problem. Each of these approaches involves the choice of some easily identifiable surrogate that is assumed to coincide with the existence of a valid state interest in asserting jurisdiction. The common law approach assumes a concurrence between state interests and the gist of an offense. The attempt standard, though never analyzed in such terms, seems to assume a similar concurrence between state interests and the creation of substantive liability. ${ }^{103}$ The integral relation approach finds this concurrence between state interests and the existence of a plan. As the analysis above has demonstrated, none of these approaches provides a rational rule for jurisdiction over an interstate felony murder. The development of a rational rule requires identification of the specific interests at stake in a state's assertion of jurisdiction over a particular crime. ${ }^{104}$ Once

29 See supra note 57 and accompanying text.

${ }^{100}$ See Restatement, supra note $86, \$ \$ 401-403$.

101 See supra notes 57-62 and accompanying text.

${ }^{102}$ The same problem was central to the development of the law of conflict of laws. The common law solution was to develop rules that promoted clarity and uniformity of result while preserving sovereign interests. These rules were described in terms of vested rights in a cause of action. Dissatisfaction with the results produced by this system led to the development of a number of escape mechanisms, such as renvoi and public policy arguments. Later, statutory solutions were attempted. In the 1950's, many courts-influenced by commentators led by Brainerd Currie-shifted to an ad hoc, case by case interest analysis. This approach has been superseded in some jurisdictions by a proliferation of new systems for resolving choice-of-law problems. Beneath all of these varied approaches the same basic tension has lurked: how can state interests be accommodated within a framework of clear rules that will promote uniformity and predictability of result? See R. CRAMTON, D. CURRIE \& H. KAY, supra note 23 , at 1-379.

103 See supra note 79.

104 The analysis proposed here is essentially identical to that used in choice-of-law 
these specific interests are identified, a rule capable of protecting them can be developed.

The law of criminal jurisdiction in the United States has never chosen to define the relevant state interests as broadly as they are defined under international law. ${ }^{105}$ In common law countries, criminal jurisdiction has developed almost exclusively along the lines of the territorial principle. ${ }^{106}$ Territorial analysis focuses on the place of commission. In a sense, territoriality simply serves as an approximation for the results of a more complete interest analysis. Territoriality is more accurately described, however, as a limiting factor in defining valid state interests in asserting jurisdiction. There is no need under a regime of territorial analysis to examine the specific interests that underlie a criminal prohibition; territorial commission is held to be both necessary and sufficient to raise valid state interests.

The review of the international law of criminal jurisdiction demonstrates, however, that territoriality is only one of several principles under which state interests may be found. Valid assertions of jurisdiction are equally well justified on the basis of either regulatory or protective principles; the state may well enact a criminal prohibition in order to further interests beyond the prevention

problems. See, e.g., Allstate Ins. Co. v. Hague, 449 U.S. 302 (1981); Pacific Employers Ins. Co. v. Industrial Accident Comm'n, 306 U.S. 493 (1939). Constitutional questions of in personam jurisdiction, like choice-of-law questions, are also analyzed with reference to state interests defined in terms of contacts between the parties, the transaction giving rise to the litigation, and the forum state. See, e.g., Kulko v. Superior Court, 436 U.S. 84, 92 (1978); McGee v. International Life Ins. Co., 355 U.S. 220, 222 (1957); International Shoe Co. v. Washington, 326 U.S. 310, 316 (1945). The Supreme Court has been careful to note that jurisdiction and choice of law are not identical and that the two questions may yield different answers in some cases. See World-Wide Volkswagen Corp. v. Woodson, 444 U.S. 286, 294 (1980); Hanson v. Denckla, 357 U.S. 235, 254 (1958). Jurisdictional analysis focuses more closely on the relationship between the forum and the defendant than choice-of-law analysis, which is concerned exclusively with the relationship between the forum and the transaction giving rise to the litigation. See World-Wide Volkswagen, 444 U.S. at 294; Hanson, 357 U.S. at 254 . These differences do not affect the analysis proposed here. It is only at the extremes, where jurisdiction is asserted on tenuous grounds, that jurisdictional analysis and choice-of-law analysis yield different results. See World-Wide Volkswagen, 444 U.S. at 254 (holding that defendant who sold plaintiff a car that was involved in an accident in Oklahoma had insufficient contacts with Oklahoma for its courts to have in personam jurisdiction, but Oklahoma law may have been applicable). Interstate felony murders do not approach these extremes; where a defendant either commits a felony or causes a death in a state, sufficient contacts exist to permit that state constitutionally to exercise jurisdiction or apply its own law. In any event, there has never been choice of law in criminal prosecutions as an historical matter: "the question of jurisdiction and that of governing law always receive the same answer." R. LeFlar, American Conflicts LAw § 111, at 224 (3d ed. 1977).

${ }^{105}$ See supra notes 84-98 and accompanying text.

${ }^{108}$ See supra note 15 and accompanying text. 
of territorial commission. ${ }^{107}$ The important question is whether some reason exists to restrict jurisdictional interests to those derived from territoriality, or whether strict territorial analysis should be abandoned in favor of an analysis that examines the specific interests sought to be furthered through particular criminal prohibitions. ${ }^{108}$

As a matter of legal theory, there is nothing sacrosanct about territoriality. Alternative bases of jurisdiction are not precluded to the states;" "save for the powers committed by the Constitution to the Union, [each state] has retained the status of a sovereign." 110 In formulating rules for jurisdiction over interstate crime, the states possess virtually the same flexibility as do independent nations. ${ }^{111}$

As a matter of common practice, courts have not failed to abandon strict territorial analysis when it has suited their needs. For instance, it has long been recognized that the state in which the effects of a crime are felt can assert jurisdiction although none of the relevant acts occurred there. ${ }^{112}$ Various state courts have abandoned territorial analysis in cases of bribery, ${ }^{113}$ failure to meet child support obligations, ${ }^{114}$ duelling, ${ }^{110}$ betting on election outcomes, ${ }^{116}$ absentee voter irregularities, ${ }^{117}$ and remarriage without approval of the court.18 Most of these cases involve statutes that were enacted to advance state interests other than the prevention of territorial commission.

${ }^{207}$ See supra note 98 and accompanying text.

${ }^{103}$ Of course, such an analysis would not eliminate territorial considerations. The fundamental premise of territoriality, that territorial commission raises a state interest, is entirely accurate; the present analysis merely suggests that is not exhaustive.

${ }^{109}$ Restatement, supra note 86, § 402 reporter's note 3; see Skiriotes v. Florida, 313 U.S. 69, 77 (1941); J. Hall, B. George \& R. Force, Criminal Law and Procedure 909-10 (3d ed. 1976); George, supra note 15, at 617, 636; Perkins, supra note 8, at 1163.

110 Skiriotes v. Florida, 313 U.S. 69, 77 (1941).

11 The availability to the states of a nationality principle to justify punishing citizens for acts committed in other states may be limited by the full faith and credit clause of the Constitution, U.S. ConST. art. IV, \& 1. See supra note 91.

${ }^{112}$ See Strassheim v. Daily, 221 U.S. 280, 284-85 (1911); Dealy v. United States, 152 U.S. 539, 546-47 (1894); Commonwealth v. Welch, 345 Mass. 366, 370-71, 187 N.E.2d 813, 816 (1963); Hanks v. State, 13 Tex. Crim. 289, 308-09 (1882); J. Bishop, CommentaRIEs on the CRiminal Law \$§ 109-110 (7th ed. 1882). (1963).

113 See, e.g., Commonwealth v. Welch, 345 Mass. 366, 370-71, 187 N.E.2d 813, 816

114 See, e.g., State v. Peeples, 112 S.C. 310, 312, 99 S.E. 813, 814 (1919) (determination of venue within state).

113 See, e.g., People v. Merrill, 2 Parker's Crim. R. 590, 595 (N.Y. 0.\&.T. 1855).

116 See, e.g., Commonwealth v. Collier, 181 Ky. 319, 319-20, 204 S.W. 74, 74-75 (1918).

${ }^{117}$ See, e.g., State ex rel. Chandler v. Main, 16 Wis. 398, 412-13 (1863).

138 See, e.g., State v. Mueller, 44 Wis. 2d 387, 171 N.W.2d 414, 418 (1969). 
Even where the territorial principle has not been abandoned outright, it has been stretched considerably to find jurisdiction in cases that do not clearly implicate territorial interests. The use of legal fictions in common law jurisdictions ${ }^{119}$ is a prime example of this practice. Statutory and judicial standards such as the sufficiency of activity or integral relation tests have had the same effect. By permitting an exercise of jurisdiction over an offense jurisdictionally significant elements of which were commited elsewhere, these tests implicitly recognize that in some cases states may extend their powers beyond their borders. Thus, while the territorial principle continues to dominate the law of criminal jurisdiction, ${ }^{120}$ its position is far from unassailable.

An approach that relies exclusively on the territorial principle is undoubtedly simpler to use than an approach requiring an analysis of all the state interests underlying a particular criminal prohibition. No one questions the power of the state in which the offense was "committed" to assert jurisdiction, and under the territorial principle, only the territorial interest need be considered and accommodated. ${ }^{121}$ While this principle precludes a court from asserting valid interests other than territorial commission, it relieves the court of the burden of ascertaining and defining those interests and balancing them against the territorial interest. If a state were forced to choose one approach for the development of all jurisdictional rules, the territorial approach might well be the most efficient. No such choice need be made, however. Where an offense is established to further an interest other than preventing the in-state commission of an act, and that interest lends itself to the formulation of a jurisdictional rule in a manner no more complicated than does the territorial approach, there is no reason to base the jurisdictional rule for the offense on the territorial approach. As the analysis below will demonstrate, felony murder is such an offense.

110 See supra notes 24-30 and accompanying text.

${ }^{120}$ See Perkins, supra note 8, at 1164; Rotenberg, supra note 15, at 773 \& n.56.

121 At common law this involved isolating the gist of the crime. See Levitt, supra note 8, at 324; Perkins, supra note 8 , at 1157-62. Statutory reformations have retained this approach in its basic form; commission within the territory is still both necessary and suffcient for a state's assertion of jurisdiction. See, e.g., Model Penal Code $§ 1.03$ (Tent. Draft No. 5,1956$)$. 


\section{State Interests and Felony Murders}

The felony-murder rule is an aberration in the criminal law. It ignores the general principle that criminal liability for causing a particular result is not established in the absence of some culpable mental state with respect to that result. ${ }^{122}$ As a consequence of this peculiarity, the felony-murder doctrine has been a source of considerable discussion, almost all critical. ${ }^{123}$

Despite this almost universal criticism, the felony-murder rule persists in all but four states. ${ }^{124}$ Although the drafters of the Model Penal Code sought to lessen the harshness of the felony-murder rule by importing into it a mens rea requirement of "extreme indifference to the value of human life,"125 only three states have enacted versions of this provision. ${ }^{128}$ Most states have retained the felony-murder rule as a basis for the highest degree of criminal homicide, and its disappearance seems unlikely. ${ }^{127}$

Felony murder is said to be premised upon one of three alternative theories. One view finds, as a justification for the felony-

${ }_{122}$ See People v. Washington, 62 Cal. 2d 777, 780, 402 P.2d 130, 133, 44 Cal. Rptr. 442, 445 (1965) (felony-murder rule "ascribes" intent to felon); W. LAFAve \& A. Scotr, supra note 79 , at 560 (1972).

${ }^{123}$ See, e.g., Model Penal Code $\S 201.2(1)(b)$ comment at 37-38 (Tent. Draft No. 9, 1959); J. Hall, General Principles op Criminal Law 455 (1st ed. 1947); W. LaFave \& A. Scott, supra note 79, at 545-60; T. Macaulay, A Penal Code Prepared by the Indian Law Commissionzrs, Note M, 64-65 (1837), reprinted in S. Kadish \& M. Paulsen, Criminal Law AND Its Processes 279-80 (3d ed. 1975); Crum, Causal Relations and the Felony Murder Rule, 1952 Wash. U.L.Q. 191; Fletcher, Reflections on Felony Murder, 12 Sw. U.L. Rev. 413 (1980-81); Hurst, Criminal Law: The Felony-Murder Doctrine Repudiated, 36 Ky. L.J. 106 (1947-48); Moesel, A Survey of Felony Murder, 28 TEмp. L.Q. 453 (1955); Morris, The Felon's Responsibility for the Lethal Acts of Others, 105 U. PA. L. Rev. 50 (1956); Turner, The Mental Element in Crimes at Common Law, 6 CAmbridge L.J. 31, 54-66 (1936-38); Note, Felony Murder as a First Degree Offense: An Anachronism Retained, 66 Yale L.J. 427 (1957); Note, Recent Extensions of Felony Murder Rule, 31 IND. L.J. 534 (1956); 65 Colum. L. Rev. 1496 (1965).

124 The felony-murder rule has been expressly abolished in Hawaii, Kentucky and Michigan. See Fletcher, supra note 122 , at 415 . Ohio has effectively abolished the rule by treating deaths resulting from felonies or during the commission of a felony as involuntary manslaughter. OHIo Rev. Code ANN. § 2903.04(A) \& (C) (Baldwin 1981).

125 Model Penal Code $\$ 201.2(1)$ (b) \& comment at 39 (Tent. Draft No. 9, 1959).

${ }^{226}$ See ARK. Stat. Ann. § 41-1501(1)(a) (1977); Del. Codz AnN. tit. 11, § 636(a)(2) (1979); N.H. Rev. Stat. ANN. § 630:1-b I(b) (1974).

${ }_{127}$ See S. KaDISH \& M. PAULSEN, supra note 122, at 281; Fletcher, supra note 122, at 415. Many states have restricted the felony-murder rule legislatively by limiting its application to a narrowly restricted class of felonies. See, e.g., Criminal Code of 1961 \$ 9-1, ILL. Rzv. Stat. ch. 38, § 9-1 (1981); Iowa Cods § 707.2 (1978); MrNN. Stat. § 609.185 (1963). Other states have similarly restricted the felony-murder rule by way of judicial decisions. See, e.g., People v. Satchell, 6 Cal. 3d 28, 33-34, 489 P.2d 1361, 1365, 98 Cal. Rptr. 33, 36-38 (1971); People v. Phillips, 64 Cal. 2d 574, 582-83, 414 P.2d 353, 360, 51 Cal. Rptr. 225, 232 (1966). 
murder rule, a taint inherent in causing a death. ${ }^{128}$ Emphasizing the states' abhorrence of the death of an individual at the hands of another person, this view imports the intent to commit the felony as creating a constructive intent to commit what is, in reality, an unintended killing. A second view of felony murder contends that the defendant, by engaging in a felony, lowers the threshold of moral responsibility the state must show to punish the resulting death. ${ }^{129}$ Perhaps a vestige of the ancient view of criminals as "outlaws," this theory imposes the risk of additional punishment for deaths that may occur in the course of a felony upon felons by virtue of their status as felons. ${ }^{130} \mathrm{~A}$ third and more recent view sees the felony-murder rule as aimed primarily at deterring felonies by imposing on felons a risk of additional punishment should a death occur in the course of their felonies. ${ }^{131}$

Translating any of these three purposes into a rule for jurisdiction over an interstate felony murder is easily done. Under the first view, the taint inherent in death is the impetus behind creation of the felony-murder offense. Under this analysis, the state in which the death occurs has an interest in asserting jurisdiction over the entire offense; the state where only the felony occurred has no apparent interest in doing so, although it may still assert jurisdiction to prosecute the underlying felony. Adoption of the second view, lowered threshold, yields a different result. The lowered threshold view sees behind the felony-murder rule a state interest in punishing felons as felons. In this view, it is the state where the felony occurred that has an interest in asserting jurisdic-

128 See Fletcher, supra note 122 , at 426 ; $c$. G. Fletcher, Rethinking Criminal Law $\S$ 5.1.1, at 343-50 (1978) (discussing taint as a general principle underlying the law of criminal homicide).

129 See G. FlETCHER, supra note 127, at 321-40; J. HALl, supra note 122, at 455; W. LaFave \& A. ScotT, supra note 79, at 560; Fletcher, supra note 122, at 426-47; Turner, supra note 122, at 43; see also People v. Aaron, 409 Mich. 672, 708-13, 299 N.W.2d 304, 31619 (1980) (abolishing the felony-murder rule).

${ }^{130}$ See Fletcher, supra note 122 , at 427.

131 See People v. Washington, 62 Cal. 2d 777, 781, 402 P.2d 130, 133, 44 Cal. Rptr. 442, 445 (1965); Commonwealth v. Thomas, $382 \mathrm{~Pa}$. 639, 644, 117 A.2d 204, 205-06 (1955) (overruled in Commonwealth v. Redline, $391 \mathrm{~Pa} .486,508,137$ A.2d 472, 482 (1958)); Commonwealth v. Almeida, 362 Pa, 596, 629-30, 68 A.2d 595, 611-12 (1949), cert. denied, 339 U.S. 924 (1950); Morris, supra note 122, at 67; see also O.W. HoLmEs, The Common LAw 58-59 (1938 ed.) ("[ilf certain acts are regarded as peculiarly dangerous under certain circumstances, a legislator may . . . require[] a man to find out present facts, as well as to foresee future harm, at his peril"); T. MACAuLAY, supra note 122, at Note M, 64-65. This rationale has been criticized extensively. See, e.g., Model Penal Code § 201.2(1)(b), comment at 3739 (Tent. Draft No. 9, 1959); T. MacaulaY, supra note 122, at Note M, 64-65; Morris, supra note 122, at 67-68 \& n.77. Macaulay suggests that executing every fiftieth or one hundredth felon would be more effective. T. Macaulay, supra note 122 , at Note M, 64-65. 
tion. Where, as in most interstate felony-murder cases, the underlying felony has occurred in both states, both states would have a valid claim for asserting jurisdiction. ${ }^{132}$ Adoption of the third view, deterrence, provides a similar result. Under this view, the felonymurder rule expresses a state interest in deterring felonies by imposing additional punishment upon persons who cause death in the course of committing felonies; accordingly the state where the felony occurred would have a clear interest in asserting jurisdiction.

The rules discussed above bear an apparent similarity to common law rules. Both these rules and the common law rules are designed to protect state interests; both involve the choice of a single element of the offense as of exclusive jurisdictional significance, with the administrative advantages associated with that choice. This apparent similarity is somewhat deceptive. Instead of assuming, as the common law does, that for all offenses there is a concurrence between the existence of a state interest and the in-state occurrence of some arbitrarily chosen gist of an offense, these rules are designed to further the specific interests behind the felonymurder rule. Thus, rules of jurisdiction over interstate felony murder developed through state interest analysis preserve the pragmatic advantages of common law rules, and are defensible as rational. The relationship between any of these rules and the interests it serves is articulable, and it can be demonstrated that the rule fulfills the purposes for which it is designed. The state interest approach is thus superior to both the common law approach and the current modern approaches, sufficiency of activity and integral relation.

To apply the state interest approach, a court must decide what purpose underlies the state felony-murder rule. Generally, the court will have little information upon which to base its choice. Felony murder is a very old crime, ${ }^{133}$ and its persistence may be

132 Similarly, where the law of the state where the felony occurred views the felonymurder rule as expressing a policy related primarily to the felony, while the law of the state where the death occurred views the felony-murder rule as expressing a policy related primarily to the death, both states would have valid claims to jurisdiction.

Situations in which dual jurisdiction exists may present further problems such as venue or double jeopardy. Although a complete discussion of these problems is beyond the scope of this comment, these problems seem more hypothetical than real. In any event, these problems are not unique to felony murder. The possibility of dual or multiple jurisdiction has long existed under the law. It exists, for example, whenever a statute grants jurisdiction based on partial commission. Hence, the analysis proposed here merely provides the opportunity for additional situations in which already existing problems may become manifest.

1ss Two cases often cited as having first formulated the felony-murder rule are Lord Dacres' Case, Moore 86, 76 Eng. Rep. 458 (K.B. 1535), and Mansell \& Herbert's Case, 2 
predominantly the result of legislative or judicial inertia. This circumstance is not a major obstacle, for courts frequently interpret legislative purposes with little available information to guide their decisions. An incorrect choice is merely a misexpression of legislative intent and, as such, is subject to ready correction by the legislature. ${ }^{134}$

Among the inherent taint, lowered threshold, and deterrence rationales, the third clearly seems to be the most defensible choice. A shift in judicial and legislative thinking from the earlier inherent taint and lowered threshold rationales to the deterrence rationale is largely responsible for the persistence of the felony-murder doctrine. The pre-eminence of the deterrence rationale is evident from the fact that judicial and scholarly discussion of felony murder in the last half century, centering on the merits of extending the doctrine to include deaths caused by victims and police responding to felonies, has been couched primarily in terms of the deterrence rationale. ${ }^{135}$ While many remain skeptical of the actual deterrent effect of the felony-murder rule, ${ }^{136}$ deterrence itself is a universally accepted rationale for the imposition of criminal sanctions. Inherent taint and lowered threshold, on the other hand, express ancient prejudices and rely on emotional appeal rather than any sort of socially meaningful and methodologically defensible state interests. ${ }^{137}$ Doctrines of a like nature have been eliminated from every other area of the criminal law. ${ }^{138}$ Criticism of the inherent taint and lowered threshold rationales has questioned their ultimate va-

Dyer 128b, 73 Eng. Rep. 279 (Q.B. 1558). See People v. Aaron, 409 Mich. 672, 689-92, 299 N.W.2d 304, 307-09 (1980) (noting that while the cases are frequently cited, it is arguable that neither actually enunciates a felony-murder rule). Sir Edward Coke gave the doctrine its first undisputed articulation. See 3 E. CoKe, Institutes of the Laws of England *56. ${ }^{194}$ For a discussion of the roles of court and legislature in statutory interpretation, see E. Levi, An Introduction to Legal Reasoning 27-57 (1949).

1ss See, e.g., People v. Washington, 62 Cal. 2d 777, 781, 402 P.2d 130, 133, 44 Cal. Rptr. 442,445 (1965) ("The purpose of the felony-murder rule is to deter felons. . . . This purpose is not served by punishing them for killings committed by their victim."); Commonwealth $v$. Thomas, $382 \mathrm{~Pa} .639,642,117$ A.2d 204, 205 (1955) (policy behind felony-murder rule, protecting human life, extends to holding felon liable for "any death" resulting from the felony) overruled, Commonwealth v. Redline, $341 \mathrm{~Pa} .486$, 508, 137 A.2d 472, 482 (1958); Commonwealth v. Almeida, 362 Pa. 596, 605, 68 A.2d 595, 600 (1949) (same); Morris, supra note 122, at 66-67 (discussing deterrence rationale of Thomas and Almeida).

1se See supra notes 122, 130.

${ }^{137}$ Cf. Note, Recent Extensions of Felony Murder Rule, supra note 122, at 543 ("[T] felony-murder doctrine gives rise to what can only be described as an emotional reaction, not one based on logical and abstract principles.").

${ }^{138}$ See People v. Aaron, 409 Mich. 672, 708-13, 299 N.W.2d 304, 316-19 (1980). 
lidity within a coherent, modern criminal jurisprudence, ${ }^{139}$ and rightly so. So long as a better alternative exists, anachronistic rationales that are not easily reconciled with general principles of criminal jurisprudence and that function mainly as instruments of public vengeance should not be imputed to the legislature. Unless there are clear indications of a contrary legislative policy, the deterrence rationale is by far the most compelling of those available for the felony-murder rule. Accordingly, in a case of interstate felony murder, only the state where the underlying felony was committed has a valid interest in asserting jurisdiction over the offense. ${ }^{140}$

\section{ConcLusion}

If a felony committed in one state results in a death in another and the accused is prosecuted in either for homicide under the felony-murder rule, the court must first establish its jurisdiction to hear the case. The court's jurisdiction depends upon the existence of a valid state interest. Since the most compelling interest behind the felony-murder rule is the deterrence of felonies, the court's jurisdiction depends upon whether the prosecution will effectuate this policy. Only if the felony occurred within the state does a valid state interest sufficient to justify an assertion of jurisdiction exist.

Larry Kramer

139

The underlying rationale for the felony-murder doctrine-that the offender has shown himself to be a "bad actor," and that this is enough to exclude the niceties bearing on the gravity of the harm actually committed-might have been defensible in early law ... but it is surely repugnant to that noble and active confidence, which a free people ought to possess in the laws of their constitution, the rule of their actions.

J. Hall, supra note 122, at 455; see also People v. Aaron, 409 Mich. 672, 710, 299 N.W.2d 304,318 (1980) ("While it is understandable that little compassion may be felt for the criminal whose innocent victim dies, this does not justify ignoring the principles underlying our system of criminal law.").

${ }^{140}$ Of course, the jurisdiction in which the killing itself occurs would have a valid interest in prosecuting that killing under a theory other than felony murder, since the primary state interest behind the passage of statutes prohibiting homicides is the prevention of intentional, reckless or negligent killings within the state which enacts the homicide statute. Moreover, in many cases the felony may be deemed to have occurred in both states, in which case the state where the death occurred will also be a state in which the felony occurred and therefore will also have an interest in prosecuting under a felony-murder theory. See supra note 131 and accompanying text. 